\title{
Report of the Managing Director to the International Monetary and Financial Committee on the IMF in the Process of Change
}


INTERNATIONAL MONETARY FUND

Report of the Managing Director to the International Monetary and Financial Committee on the IMF in the Process of Change

April 25, 2001

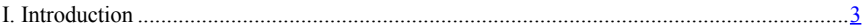

II. Refocusing the Work of the Fund ...........................................................................

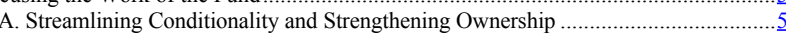

B. Fund Financing Facilities.

Contingent Credit Lines (CCL) ....................

Repurchase Expectations...........................................................................

Surcharges on Credit Outstanding Above a Threshold Level.............................. $\frac{8}{8}$

Extended Fund Facility..........................................................................

Post-Program Monitoring …

C. Involving the Private Sector in the Resolution of Crises .........................................

Restructuring International Sovereign Bonds.............................................. 9

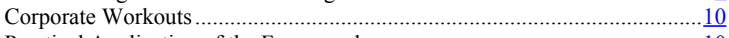

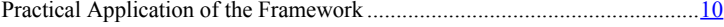

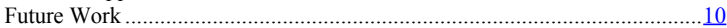

D. External Vulnerability …........................................................................ 11

Reserve Adequacy and Management ..........................................................

Early Warning Systems and Vulnerability Indicators .................................13

E. Standards and Codes.......................................................................................

F. Prioritizing Technical Assistance ......................................................................

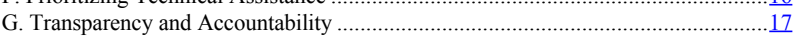

III. Strengthening Financial Sector Work and Surveillance .............................................. 18

A. International Capital Market Surveillance.........19

Recent Work on International Capital Markets ...........................................

International Capital Markets Department .......................................................

Capital Markets Consultative Group ........................................................

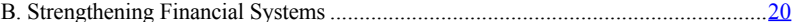

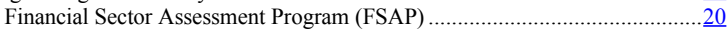

Offshore Financial Centers (OFCs) ……................................................

C. Combating Money Laundering …………………............................................ 
Boxes

1. A Quiet Revolution in Reserves Policies........................................ 14

Figures

1. Average Number of Structural Conditions per Program Year by Type of Country ...... $\underline{25}$

2. Distribution of Structural Conditions by Economic Sector..........................

Appendix Tables

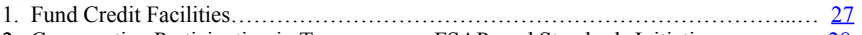

2. Comparative Participation in Transparency, FSAP, and Standards Initiatives........... $\frac{28}{29}$

3. Publication of PINs, Summings Up and Policy Papers...............................

4. Institutions Cooperating in the FSAP by Providing Experts.......................... 


\section{INTRODUCTION}

1. This report provides an update on progress in refocusing the work of the Internationa Monetary Fund on its core activities since the Managing Director's report in September 2000. ${ }^{1}$ In Prague, the membership endorsed the Managing Director's vision of the future role of the Fund, focusing on crisis prevention and resolution, promoting international financial stability as a global public good, and actively participating in the international efforts to make globalization work for the benefit of all. In the period since then, much has been done toward realizing these objectives and making the Fund more effective, but the full realization of this vision will require unflagging work in the period ahead.

2. A main lesson from recent events is that crisis prevention must be at the heart of the Fund's activities, and the initiatives described in this report reflect this. They show how the Fund recognizes the need continuously and promptly to adapt its policies so as to fulfill its mandate as conditions change in the increasingly integrated international financial system.

3. During the last year, the Fund's facilities were reviewed and streamlined to allow them to support more effectively members' efforts to prevent and resolve crises and to ensure a more efficient use of Fund resources. Moreover, the Fund has taken further steps towards streamlining conditionality in its arrangements, to make its assistance more effective and program ownership stronger. The Fund is also working to strengthen its collaboration and cooperation with other participants in the international financial system, in particular with the World Bank, with the aim of ensuring an appropriate division of responsibilities. During the period ahead, work will continue on the most effective means to streamline Fund conditionality, while giving full attention to the reforms needed to assure sustainable growth in members whose programs are supported with Fund and other official resources. On the basis of this experience, the Fund's guidelines on conditionality will be reviewed, and revised as necessary.

4. Experience has been gained in implementing the framework for the involvement of the private sector in crisis resolution. Work has been done on two issues which have a bearing on the development of the framework - restructuring international sovereign bonds and corporate sector work outs. In the cases of Argentina and Turkey the catalytic approach has been complemented by arrangements to secure the continued involvement of private creditors.

5. The Fund has also been implementing an ambitious agenda of initiatives to strengthen crisis prevention and improve the functioning and stability of the international financial system. Multilateral surveillance and bilateral surveillance under Article IV are the main

\footnotetext{
${ }^{1}$ This report discusses the work underway in strengthening the framework for private sector involvement in the resolution of crises in response to a request from the International Monetary and Financial Committee (IMFC) in
} September 2000

\section{(C)International Monetary Fund. Not for Redistribution}


vehicles for pursuing this agenda. In the regular reviews of economic policies and developments at the national and international levels, a stronger emphasis is being placed on the vulnerabilities of individual members and of the international system, and the work on standards and codes and the increased transparency of the Fund's own views and activities is providing greater information to markets for their own risk assessment. The imminent establishment of an independent Evaluation Office should also make a substantial contribution to the effectiveness of the Fund's work.

6. Major steps have been taken toward strengthening financial sector surveillance and making the Fund a center of excellence for the stability of the international financial system. These include the decision to create a new International Capital Markets Department as a focus for the Fund's work on international financial markets and external vulnerability; the establishment of the Capital Markets Consultative Group; placing the Financial Sector Assessment Program (FSAP) on a permanent basis and moving forward with assessments of offshore financial centers (OFCs). At the request of the International Monetary and Financial Committee (IMFC), the Fund, in collaboration with the World Bank, is also enhancing its contribution to international efforts to combat money laundering.

7. Poverty remains the greatest challenge facing the international community. The International Development Goals (IDGs) set by UN conferences held in the 1990s and adopted by the Millennium Summit provide a vision of a world in which the burden of poverty and its miseries are much reduced. Within this vision, the Fund, in collaboration with the Bank and others, has an important role to play. In this regard, the efforts to reduce the debt of the Heavily Indebted Poor Countries (HIPCs), to ensure that debt relief and other resources are used to tackle poverty, and to promote broad-based and sustainable growth through the Poverty Reduction and Growth Facility (PRGF) are central to the Fund's work Much has been done since the Annual Meetings in Prague to achieve the speedy implementation of the HIPC Initiative and to make the early stages of the Poverty Reduction Strategy Paper (PRSP) approach a success, but major challenges remain. A separate report ${ }^{2}$ prepared by the Development Committee discusses the substantial progress achieved, some of the challenges, and proposals to address these challenges.

8. Strong cooperation between the Fund and the World Bank is a crucial issue for both institutions to enhance the effectiveness of their respective operational work. In specific areas, such as financial sector assessments, standards and codes, reserve and debt management and in our work in the poorer countries, Bank/Fund collaboration is proceeding well. Improving cooperation, including through a clearer division of labor is, however, still an objective in other important areas such as conditionality, technical assistance, and capacity building. Stronger efforts in this direction are critical in ensuring further progress in these important initiatives.

2 "Fighting Poverty and Strengthening Growth in Low-Income Countries," Joint Memorandum from the President of the World Bank and the Managing Director of the International Monetary Fund, April 18, 2001.

\section{CInternational Monetary Fund. Not for Redistribution}


9. The range of initiatives launched in the last several years to strengthen crisis prevention are now being implemented and integrated into Article IV surveillance. This section reviews the considerable progress since the 2000 IMFC meetings in Prague in

refocusing the Fund, including the major efforts to streamline conditionality; restructure Fund facilities; further the work on private sector involvement in the resolution of crises; and implement the initiatives on crisis prevention, in particular, vulnerability assessment, standards and codes, and transparency.

A. Streamlining Conditionality and Strengthening Ownership

10. The Fund is streamlining conditionality with the objective of promoting greater ownership and strengthening the implementation of programs. On March 7, 2001, the Executive Board discussed the issues and principles related to conditionality against the background of the experience of the past decade. ${ }^{3}$ Executive Directors agreed that conditionality remains indispensable. They noted that there had been a major expansion of conditionality, particularly in the structural area, including a marked rise in the average number of structural benchmarks per program (Figure 1). This expansion was, in part, a reflection of the increased emphasis on growth as a policy objective as well as the fact that the Fund has been intensively supporting countries in which the correction of sometimes massive structural distortions were fundamental to addressing macroeconomic and external imbalances. It was observed that the Fund's conditionality had remained concentrated on its core areas (Figure 2). However, it was also noted that the application of some conditionality outside these areas gave rise to concerns that the Fund was overstepping its mandate and expertise. In addition, the broad coverage of many letters of intent and memoranda of economic and financial policies had created confusion about the boundaries of conditionality.

11. Against this background, Directors agreed that there was a need to streamline and focus conditionality and supported the broad thrust of the Interim Guidance Note on streamlining structural conditionality issued by the Managing Director in September 2000. This note states that structural reforms that are critical to the achievement of a program's macroeconomic objectives will generally have to be covered by Fund conditionality; however, a more focused and parsimonious application of conditionality is envisaged for structural reforms that are relevant—but not critical — to the program's macroeconomic objectives. While these principles need to be interpreted carefully on a caseby-case basis, they shift the presumption of coverage from one of comprehensiveness to one of parsimony - thus requiring a stronger burden of proof for the inclusion of specific structural measures as conditions in an arrangement, particularly where these measures are outside the Fund's core areas. The Fund has already been putting the principles established in this note into practice in new Fund-supported programs. Recognizing that the application of

${ }^{3}$ For details see Public Information Notice, "Executive Board Discusses Conditionality", March 21, 2001

\section{CInternational Monetary Fund. Not for Redistribution}


the principles in the guidance note would involve considerable judgment case-by-case, Directors agreed that forthcoming arrangements should be examined as they are brought to the Executive Board with a view to deriving lessons for future practice. They also saw a need to clarify and strengthen the guidance covering the application of the various tools of conditionality.

12. Directors agreed that there should be a clearer distinction between the authorities' overall policy program and that part of the program that is subject to Fund conditionality. While the authorities' program will need to be comprehensive, Fund conditionality would be more focused, reflecting short-term priorities and the authorities' ability to implement reforms.

13. Directors viewed streamlining as an important part of a strategy to promote ownership of programs. They also stressed that ownership depended importantly on the process by which programs were negotiated. This process should allow authorities to consider various policy alternatives with a view to ensuring the program reflected the priorities of the country itself.

14. The process of streamlining will continue in the period ahead. The Executive Board will return to discuss these issues in light of the deliberations of the International Monetary and Financial Committee (IMFC) and lessons drawn from the early experience in implementing the guidance note. The Board will also be in a position to draw on the conclusions of two conferences planned for June, which will bring together academics, policy makers, and non-governmental organizations with different perspectives on conditionality. Comments will have been received from outside the Fund on the papers and conclusions of the March 7 Board meeting to inform future discussions. ${ }^{4}$ As the next stage, the Board will give further consideration to the application of various tools of conditionality, including policies on waivers of performance criteria and the role of program reviews, structural benchmarks, and prior actions. Later in the year, the Board will return to review the guidelines on conditionality. The aim will be to bring these guidelines into line with evolving practices, while giving due emphasis to the need for streamlining.

15. Along with streamlining conditionality, greater transparency is helping to promote ownership of programs. Nine out of ten policy intentions documents (letters of intent (LOIs) and memoranda of economic and financial policies (MEFPs)) are now published. Publication of Chairman's statements, presenting a summary of Executive Board views, is presumed and country papers are increasingly released on a voluntary basis. Fund members now, for the first time, have the opportunity to publish the staff reports on use of Fund resources.

${ }^{4}$ News Brief (NB/01/34) of April 9, 2001.

\section{CInternational Monetary Fund. Not for Redistribution}


16. In their discussion in February on the role of the Fund in relation to governance issues, Executive Directors stressed that the approach to conditionality in governancerelated areas should be consistent with the approach to conditionality in general. Directors welcomed the proactive role taken by the Fund on governance issues and the heightened attention given to governance as a key factor influencing economic performance. 5 However, they stressed that the Fund should exercise judgment and sensitivity as it moves forward, keeping in mind the need for even-handedness and the importance of country ownership in improving governance. They also reiterated that the Fund's involvement should be limited to economic aspects of governance that could have a significant macroeconomic impact. In this regard, many Directors called for further efforts to apply the test of macroeconomic relevance more explicitly.

\section{B. Fund Financing Facilities}

17. In November 2000, the Board concluded a major review of Fund financial facilities. This effort has produced a significant streamlining through the elimination of four facilities. In addition, a number of important changes were implemented that should allow the Fund facilities to play a more effective role in supporting members' efforts to prevent and resolve crises, and help ensure a more efficient use of the Fund's resources (Appendix I). ${ }^{6}$

\section{Contingent Credit Lines (CCL)}

18. A key element of the package of policy changes was a modification to the CCL to make it more attractive to potential users. Executive Directors agreed that less intensive monitoring arrangements than under other Fund facilities would be appropriate for members that had strong track records on policies and qualified for the CCL. Executive Directors also agreed that the conditions for completing the activation review should be simplified, to ensure the member using the CCL of greater automaticity in the disbursement of resources. In addition, the Board reduced the initial rate of charge to half of the surcharge under the Supplementary Reserve Facility (SRF) and also reduced the commitment fee on CCL resources.

\section{Repurchase Expectations}

19. In their review of ways to ensure the efficient use of Fund resources, Executive Directors agreed that prolonged use following the resolution of a balance of payments problem should be addressed through the introduction of time-based repurchase

${ }^{5}$ For details see Public Information Notice, "Executive Board Reviews IMF's Experience in Governance Issues", March 8, 2001

${ }^{6}$ For details see the "Summing Up by the Acting Chairman of the IMF Executive Board—Contingent Credit Lines", November 17, 2000

\section{CInternational Monetary Fund. Not for Redistribution}


expectations, which would come into force before repurchase obligations. In stand-by arrangements (SBAs), members would be expected to begin repurchases after $2 \frac{1}{4}$ years and complete repurchases after 4 years, while repurchase obligations span $3 \frac{1 / 4}{4}$ to 5 years. Under the Extended Fund Facility (EFF), members would begin repurchases after $41 \frac{1}{2}$ years, as at present, but expected repurchases would be completed in 7 years, rather than 10 years under the obligation schedule. Fund-supported programs will continue to be guided by the requirement that the member should be able to meet repurchase obligations (rather than expectations), and the meeting of expectations will signal that the member's external position is stronger than would have been dictated by this requirement. Since Fund-supported programs will not as a general rule target adjustment sufficiently rapid for members to meet repurchase expectations, it will follow that in most cases members will be considered to be in position to meet repurchase expectation only if their external position is stronger than has been projected at the time of approval of the arrangement. ${ }^{7}$

Surcharges on Credit Outstanding Above a Threshold Level

20. The Board also decided to introduce surcharges on the basic rate of charge for credit outstanding above a certain level under the credit tranches and the EFF. The surcharge would begin at a level of 100 basis points for access above 200 percent of quota, and would rise to 200 basis points with credit outstanding above 300 percent of quota. Purchases made under the SRF and under the CCL (which are already subject to special surcharges), and under the Fund's policies on emergency assistance would not be subject to the surcharge. The amount of credit outstanding under these facilities would not be taken into account in determining the applicable surcharge on other Fund credit. ${ }^{8}$

Extended Fund Facility

21. The Executive Board also decided that arrangements under the Extended Fund Facility (EFF) should be granted only in cases that fully meet the terms and spirit of the EFF Decision. These would be cases where there is a reasonable expectation that the member's balance of payments difficulties were likely to be of relatively long duration, including stemming from limited access to private capital markets, and where there is an appropriately strong structural reform program to deal with the embedded institutional or economic weaknesses. The Board agreed that extended arrangements would rarely be of a precautionary nature, since potential balance of payments difficulties are often long term and entrenched.

\footnotetext{
${ }^{7}$ However, in the case of CCLs and augmentations with SRF resources, the program will be designed on the assumption of repurchase expectations, rather than obligations.

${ }^{8}$ For details see the "Summing Up by the Acting Chairman of the IMF Executive Board—Contingent Credit Lines", November 17, 2000. Purchases outstanding before the date of this decision are not subject to the surcharge or taken into account for calculating surcharges on future purchases.
}

\section{CInternational Monetary Fund. Not for Redistribution}


22. The Board decided that enhanced post-program monitoring (PPM), with more formal involvement of the Board, would be useful in certain cases to provide an early warning of policies that could call into question a member's continued progress toward external viability. Specifically, PPM would be recommended for a member unless the member's circumstances were such that the process was determined to be unnecessary. To this end, Directors agreed that there should be a presumption that when a member's credit outstanding at the end of an arrangement exceeds a threshold of 100 percent of quota, it would ask the Fund to continue monitoring economic developments until credit falls below this threshold. The Board's discussions of PPM papers would be reflected in a Public Information Notice (PIN) and, as with other PINs, their publication would be voluntary.

\section{Involving the Private Sector in the Resolution of Crises}

23. Since the endorsement by the IMFC of the framework for the involvement of the private sector in the resolution of financial crises at its Prague meeting, ${ }^{9}$ there have been two principal strands to the Fund's work in this area. First, the framework has been developed as it relates to the restructuring of international sovereign bonds and corporate workouts. Second, the framework has been applied to two major emerging market members facing financial crises: Argentina and Turkey

\section{Restructuring International Sovereign Bonds}

24. Directors reviewed the recent experience gained with the restructuring of international sovereign bonds, and gave preliminary consideration to a private sector proposal concerning the process of bond restructuring. Directors noted that there was now a general recognition in financial markets that international sovereign bonds are not immune from debt restructuring, and that, if borrowers face severe liquidity crises, bondholders along with other creditors may need to contribute to the resolution of such crises. Directors also observed that recourse to restructuring sovereign bonds should be guided by the same principles that guide recourse to restructuring of other claims (i.e., it should be limited to exceptional circumstances when financing needs are large, and the prospects for a member in crisis regaining voluntary market access are poor). Voluntary collective action clauses in bond contracts could play a useful role in the orderly resolution of crises; their explicit introduction in bond implementation would provide a degree of predictability to the restructuring process. Exit consents, as used in the Ecuador exchange, provided an innovative, albeit controversial, initiative that could be used in the context of restructuring international sovereign bonds that do not contain collective action clauses. While recognizing that it is premature to assess the impact of different processes used to restructure international sovereign bonds, Directors expressed concern that some processes may have adverse spillover effects and could affect the efficient operation of

${ }^{9}$ Communique of the IMFC of the Board of Governors of the IMF, September 24, 2000.

\section{CInternational Monetary Fund. Not for Redistribution}


international capital markets, and urged those members that need to restructure bonds to make good faith efforts to reach collaborative agreements with their creditors.

\section{Corporate Workouts}

25. In an informal workshop, Executive Directors also discussed corporate sector workouts; in particular, their relevance for resolving corporate sector indebtedness during a systemic crisis in a fashion that helps restore financial sector stability and paves the way toward a resumption of sustainable growth. They also considered the role of workout mechanisms in promoting financial system stability.

26. In addition, there are a number of aspects of the Fund's work that have contributed to the capacity to assess medium-term viability and whether or not there is a need for debt restructuring. These include improvements in assessments of external vulnerability, the assessment of reserve adequacy, and the debt management guidelines mentioned below.

\section{Practical Application of the Framework}

27. In both Argentina and Turkey, the catalytic approach to private sector involvement was adopted in view of the expectation of continued market access by these countries, their underlying payments capacity, and the risks of alternative approaches. The specific actions to strengthen support were:

- $\quad$ For Argentina, private sector commitments included: (i) agreement with loca financial institutions to roll over maturing bonds and purchase new public issues (at market prices) of US\$10 billion; (ii) understandings with institutional investors on the purchase of new public issues of US\$3 billion; and (iii) liability management operations covering US\$7 billion of total debt (expected to reduce financing needs in 2001 by US $\$ 2.7$ billion).

- $\quad$ For Turkey, a voluntary commitment was obtained from foreign banks to maintain aggregate exposure in the form of interbank and trade-related credit lines extended to the Turkish banking system at the December 11, 2000 level. (At meetings in Frankfurt and New York, foreign banks were also asked to maintain exposure on trade lines provided directly to the nonfinancial corporate sector.) In this connection, the government also extended a guarantee on all liabilities of Turkish banks, including foreign liabilities and off-balance sheet liabilities.

Future Work

28. In the coming months work that is currently underway is expected to help strengthen the analytic underpinnings of the Fund's policy of involving the private sector in the resolution of financial crises. The Executive Board has asked for further work on promoting constructive relations between members and their creditors. The Board will also consider

\section{CInternational Monetary Fund. Not for Redistribution}


papers on strengthening the basis of assessing the pace and magnitude at which countries in crisis can regain market access. In developing further its work on the restructuring of the claims of private creditors, the Board will consider a paper concerning the relation between the treatment of Paris Club and private sector claims. Further work on other aspects of the operational framework endorsed by the IMFC is underway. ${ }^{10}$ The future work program will reflect the discussion of the IMFC on these topics.

\section{External Vulnerability}

29. Much has been done to increase the focus of Fund surveillance on member countries' vulnerability to crises, but much still remains to be done. Work is proceeding on identifying principles for prudent external liability management and developing analytical frameworks for assessing external vulnerability. The Fund has worked to assist its members in the assessment of reserve adequacy, in reserve management, and in the monitoring and management of debt with the aim of preventing crises. The Fund is also improving its work on vulnerability indicators and early warning system (EWS) models to help inform discussions with authorities on fiscal, monetary, and exchange rate policies and on the potential vulnerabilities of their economies.

30. The Fund continues its outreach and collaborative efforts in the work on external vulnerability and will also seek to mobilize technical assistance to bring essential capacitybuilding efforts in these and other areas to fruition as quickly as possible.

Reserve Adequacy and Management

31. The Fund has stepped up its efforts to assist members in the assessment of reserves adequacy, an essential aspect of preventing liquidity-related crises (Box 1). Because the provision of accurate, comprehensive, and timely data on international reserves is essential to the analysis of external vulnerability, the Fund is promoting members' use of the reserves template, which was developed in the context of the Special Data Dissemination Standard and provides a benchmark to assess the official sector's foreign currency liquidity. The adequacy of the level of reserves itself is increasingly being analyzed within an extended framework highlighting capital account-based measures for market access countries-in addition to the traditional current account-based ratios. The Fund, in collaboration with the World Bank, has hosted roundtables and hands-on working groups to help national authorities assess reserve adequacy. Stress-testing balance of payments is another promising component of the analysis of liquidity requirements. More generally, judgments on reserves adequacy

${ }^{10}$ Communiqué of the IMFC, September 24, 2000.

\section{CInternational Monetary Fund. Not for Redistribution}


will also need to take full account of other country-specific factors, in particular macroeconomic fundamentals. ${ }^{11}$

32. Reserve management is an important crisis prevention tool, and Fund staff is working on a set of draft guidelines on foreign exchange reserve management guided by the Board's discussion in May 2000. The work has benefited substantially from an outreach meeting held in July 2000 with representatives from reserve management authorities of about 30 member countries, the BIS, and the World Bank. On that occasion, participants endorsed the idea of preparing a set of broad guidelines on reserve management that would articulate objectives and principles as well as institutional and operational foundations to guide practices, while recognizing that there is no unique set of reserve management practices or institutional arrangements that is best for all countries or situations.

33. Preliminary guidelines have been circulated to this outreach group and their comments were also made available to the Fund's Executive Board. After incorporation of comments received, the draft guidelines will be further developed through consultations with a broader range of participants through regional outreach meetings that will take place over the summer of 2001. It is expected that revised draft guidelines will be submitted to the Executive Board before the September 2001 IMFC Meetings.

Debt Management Guidelines

34. The Fund and the World Bank worked together to develop a set of guidelines on public debt management to assist countries in their efforts to improve their public debt management practices and reduce financial vulnerability. An early draft of the guidelines was discussed by the Executive Boards of the two institutions. The guidelines were subsequently revised to reflect views of Directors and comments received during an extensive consultation with more than 300 representatives from 122 countries and 19 institutions. The exercise was designed to strengthen the ownership of the guidelines by Fund members and to help ensure that they are in line with sound practices and are well understood and accepted by policymakers, debt managers, and market participants.

35. At a Board meeting in March 2001, Executive Directors welcomed the revised guidelines as a useful instrument to assist countries in their efforts to improve their public debt management practices and reduce financial vulnerability. ${ }^{12}$ Directors emphasized the importance of coordination between debt management, fiscal, and monetary authorities, and indicated that the implementation of the guidelines will vary with a country's circumstances

${ }^{11}$ The Fund's work on reserve adequacy and the debt management guidelines (see below) will be presented at a joint World Bank/Fund seminar on reserves scheduled for April 28, 2001 in connection with the April 2001 IMFC meetings

${ }^{12}$ For details see News Brief, IMF and World Bank Publish Public Debt Management Guidelines", April 13, 2001. 
and institutional constraints. They also stressed the important role that technical assistance from the Bank and Fund will play in assisting countries to implement the guidelines. They noted that the guidelines at times can serve as useful benchmarks for both country authorities and the Fund in the context of Article IV surveillance.

36. The guidelines have been published by the Fund and World Bank on their external websites. ${ }^{13}$ A report containing sample case studies of countries that have developed strong systems of public debt management will be prepared by Fund and World Bank staffs in due course.

Early Warning Systems and Vulnerability Indicators

37. The Fund is strengthening its methodology for assessing the likelihood of foreign exchange crises. Early Warning Systems (EWS) — formal models that estimate the probability of crises from a set of variables - are important tools to monitor risks that arise from problems in member countries and conditions in international markets. Results of EWS work and analyses of relevant indicators are increasingly used to inform and strengthen Article IV consultation discussions. The work on EWS has also provided analytical support for the use of key indicators of vulnerability now reported in Article IV consultation staff reports. While EWS and indicators of vulnerability are helpful tools in motivating a discussion on vulnerability with country authorities, the results must be qualified by individual country circumstances. The limitations of these models and of vulnerability indicators as crisis predictors has necessitated continued caution in their use for Article IV surveillance.

38. Efforts continue to strengthen and systematize further the Fund's approach to analyzing external vulnerability, including through research, internal working groups, and external outreach, such as the collaboration with the FSF Secretariat focused on vulnerabilities in global capital markets. Work on vulnerability is also conducted in the context of the work on standards and the Financial Sector Assessment Program (FSAP), as discussed below. This includes strengthening the quality, provision, and dissemination of data both within and outside the Fund; and adherences to good practices in fiscal, monetary, and financial policy transparency. The establishment of an International Capital Markets Department, discussed below, is also intended to strengthen the Fund's approach to identifying and reducing members' vulnerability.

${ }^{13}$ See News Brief, "IMF and World Bank Publish Public Debt Management Guidelines", April 13, 2001.

\section{CInternational Monetary Fund. Not for Redistribution}


Box 1: A Quiet Revolution in Reserves Policies

In May 2000, Executive Directors discussed a staff paper entitled Debt- and Reserve-Related Indicators of External Vulnerability. The paper elaborated on the idea put forward by a number of academics and policy makers, that reserve adequacy depends not only on the current transactions of a country (the conventional ratio of reserves to imports), but also on its capital (especially, short-term debt-servicing) needs. Specifically, the paper proposes a new rule of thumb that targets coverage of short term debt by remaining maturity as the main criterion for setting reserve levels. This idea represents a "quiet revolution" in the assessment of reserve adequacy. However, judgments on reserve adequacy also need to take full account of other country-specific factors and macroeconomic fundamentals.

Action has been taking place on the research, operations, and outreach fronts. Research work has tried to gain a better understanding of the role of reserves in preventing crises, or in alleviating the negative impact of crises on output. What is the relationship between movements in the exchange rate (and hence, the exchange rate regime), the current account position, and the need for reserves? What role can "stress testing" play in evaluating reserve adequacy? What is the link between reserves and the probability of external crisis, given a set of other relevant indicators? Such questions have been, and continue to be probed, and some preliminary results are becoming available.

On the operations front, the Fund is beginning to approach the issue of assessing external vulnerability more proactively and systematically. Using the results from its research effort, married to its country-specific knowledge, the Fund is improving its assessment of external vulnerability. These assessments are communicated to the Executive Board and help inform national decision making. Fund staff reports are focusing more incisively on the issue of external vulnerability and core vulnerability indicators are now systematically included in these papers.

The success of this work hinges on extensive outreach efforts, both to publicize, and, equally important, to gain feedback from, country reserve managers on what works and what does not. Outreach has taken place in international conferences on reserve management (under the joint sponsorship of the World Bank and the Fund); seminars (such as reserves roundtables that bring together researchers and country practitioners); the solicitation of comments from a wide range of international sources on the Fund's draft Reserve Management Guidelines; courses (including at the Fund's training institutes); and discussions, in collaboration with the

World Bank, with individual countries on reserve management strategy.

The work will result in detailed guidance for Fund staff on how to approach external vulnerability. A promising new development is technical assistance on reserve portfolio management under a new World Bank program ("RAMP"). It is hoped that a closer relationship between country-based reserve managers and technical experts can further knowledge on both sides, ultimately making countries more resilient to crises, while helping to reduce their incidence. 
39. Another important vehicle to enhance crisis prevention is the Fund's work on standards and codes. The Executive Board reviewed the experience with assessing and implementing international standards and codes in January 2001. ${ }^{14}$ In response to a request from the IMFC, Executive Directors also agreed on modalities by which members' observance of standards and codes should be discussed in the context of Article IV surveillance. Directors have endorsed a list of 11 areas where standards are considered important for surveillance - while noting that not all standards are relevant for all countries at all times. During the discussion, Directors stressed the importance of maintaining the voluntary nature of standards and Reports on the Observance of Standards and Codes (ROSCs); of avoiding the use of pass-fail grades in ROSCs; of maintaining a standardized format for all ROSCs; and of giving credit for progress achieved rather than just highlighting areas where more work is needed. Directors emphasized the need for ROSCs to reflect appropriately the different conditions across the membership while at the same time preserving consistency across countries and maintaining the universality of standards. There was also a call for more outreach to the private sector, more research on the link between implementing standards and crisis prevention, and for greater prioritization in assessments.

40. The Fund and World Bank hosted a conference in March 2001 on international standards and codes. The Conference provided an opportunity for representatives of a number of emerging market and developing countries to discuss with standard setters the concerns they had about the way in which some standards have been developed and the appropriate pace of implementation. Despite these concerns, there was agreement on the value of standards to macroeconomic stability, economic performance, and improved financial decision-making. An important conclusion of the conference was a recognition by standard setters that participation in formulating standards should be broadened to ensure their greater legitimacy. Participants also discussed ways to combine appropriate differentiation in implementing and assessing standards with the need (on which there was an overwhelming consensus) for consistent international standards.

41. In March 2001, the Fund Board approved a revision of the Code of Good Practices on Fiscal Transparency as well as the accompanying Manual on Fiscal Transparency ${ }^{15}$ with the objective of placing greater emphasis in the code on the importance of fiscal data quality.

\footnotetext{
${ }^{14}$ For details see Public Information Notice, "Assessing the Implementation of Standards—An IMF Review of Experience and Next Steps", March 5, 2001.

${ }^{15}$ See Revised Manual on Fiscal Transparency and Revised Manual of Fiscal Transparency and Revised Code of Good Practices on Fiscal Transparency on IMF website at www.imf.org/standards.
}

\section{CInternational Monetary Fund. Not for Redistribution}


42. Both at the January Board meeting and at the March conference, there were calls for more, and better coordinated, technical assistance to support members' implementation of standards. At a Board meeting on technical assistance in January 2001, Executive Directors identified standards as one of the six priority areas for Fund technical assistance. They also suggested that the Fund should intensify coordination and collaboration with other providers of technical assistance, including with respect to technical assistance relating to standards and codes.

43. The pace of the production of Reports on the Observance of Standards and Codes (ROSCs) has picked up. Many more countries are volunteering for ROSCs and are requesting technical assistance to help them adopt standards and codes. Over 100 ROSCs were completed and 73 published by the end of March, an increase of 25 percent since September 2000 (Appendix II). Well over 100 ROSCs are due to be completed during the coming financial year. Progress was also made in establishing mechanisms and criteria for prioritizing assessments. Financial sector ROSCs, which are primarily generated in the context of FSAPs, will be driven by the criteria established for FSAPs by the Executive Board (see below), while priorities for Fund-led ROSCs are set by an interdepartmental task force and reviewed by Fund management.

44. Outreach exercises by the Fund and Bank have shown growing interest in the work done on standards. A number of financial institutions have indicated that they are beginning to incorporate the results of standards assessments into their risk assessments. On private sector organization is setting up an extensive database, which will track countries' observance of international standards, and major financial institutions have already subscribed to this service. Many market participants have stressed that to improve the usefulness of ROSCs for risk assessment, there needs to be comprehensive coverage of countries, higher frequency of assessments, and consistency in treatment and language between countries as well as in the packaging of information.

\section{F. Prioritizing Technical Assistance}

45. Since the $\mathbf{2 0 0 0}$ Annual Meetings, the Fund has outlined a strategy for more closely aligning technical assistance with its key policy priorities. In January 2001, the Executive Board endorsed a strategy which establishes the central role that technical assistance will play in supporting the work of the Fund in crisis prevention and management, capacity building for the HIPC/PRGF eligible countries, and in restoring macroeconomic stability in post-crisis situations. This strategy includes major changes in the way that technical assistance is prioritized and managed in order to introduce greater focus and accountability. As a result, future Fund technical assistance operations will concentrate more firmly on its core mandate and areas of competence. In addition, coordination and cooperation with other donors will be strengthened, particularly with the World Bank to ensure that important complementary areas needed for Fund technical assistance are covered. These changes have been implemented and results will begin to materialize during 2001

\section{CInternational Monetary Fund. Not for Redistribution}


46. Given the expectation that technical assistance will play a progressively more central role in the Fund's work, Executive Directors expressed concern over a potentially significant gap between demands for technical assistance and the ability of the Fund to respond. Resource constraints are already evident for the capacity building requirements of the PRGF/HIPC countries. In addition, strong and growing demands for technical assistance have arisen from recent initiatives including on standards and codes, Financial Sector Assessment Programs, tracking debt relief, assessments of offshore centers, and safeguarding Fund resources. As a consequence, the Board believed there was a need to mobilize additional technical assistance resources. Directors strongly encouraged those of its members that had not already done so, or committed to do so, to provide financing for technical assistance.

\section{G. Transparency and Accountability}

47. The Fund and member countries have done much in the last several years to increase the transparency of economic and financial data and policies. The implementation of initiatives on the Fund's new transparency has progressed significantly over the last year starting with the adoption by the Fund Board, in January 2001, of the decision and modalities underpinning the Fund's policy of voluntary publication of country staff reports. The Fund encourages the publication of country documents, while considering the need to accommodate the specific circumstances of each country.

48. Reflecting a major shift in Fund transparency and that of member countries, as of end-March 2001 sixty nine members have published 91 Article IV staff reports since June 1999 when the Board took the decision to authorize their release (see Appendix II). Public Information Notices (PINs) introduced in 1997 were published in 2000 following Article IV consultations for more than three-quarters of the Fund membership. In addition, Board discussions of regional surveillance papers; concluding statements of Article IV and other Fund missions representing the view of Fund staff; Recent Economic Developments; Selected Issues; Statistical Appendices; ROSCs; and staff papers and Fund mission concluding statements for staff-monitored programs are now routinely published.

49. There has also been greater transparency for documents on the use of Fund resources. Since the January 2001 decision to authorize the publication of country staff reports for programs, eight staff reports have been published. The release of Chairman's Statements since mid-1999 provides to the public a summary of the Fund Board's views on all programs supported by the Fund, increasing the transparency of the Fund policy advice.

50. As a step in greater ownership of Fund-supported programs by the authorities and civil society, the publication of the authorities' policy intention documents is now the rule. As of end-March 2001, 143 Letters of Intent (LOIs), Memoranda of Economic and Financial Policies (MEFPs), and Technical Memoranda of Understanding with policy content - covering over 90 percent of all policy intention documents - have been published. Interim Poverty Reduction Strategy Papers and Poverty Reduction Strategy Papers (PRSPs); documents relating to the HIPC initiative and Joint Staff Assessments of PRSPs are also

\section{(C)International Monetary Fund. Not for Redistribution}


published on the Fund website, an integral part of the open and participatory nature of this work.

51. The new procedures to facilitate the greater use of PINs following discussions on policy issues and for a more systematic release of policy papers are in place. PINs have been increasingly published for Fund Board discussions including most recently the reviews of conditionality, governance, standards and codes, FSAPs, and facilities (Appendix III).

52. The Fund Board has agreed to review periodically the policies and procedures that have shaped the dramatic change that has occurred in the release of Fund documents in recent years. The first review is scheduled for mid 2002.

53. The Fund has also continued to improve the transparency of its financial activities. The Fund's financial statements now conform fully with international standards and clearly identify the key components of the Fund's asset and liabilities. The Fund's external website now contains current information on all elements of the Fund's financial activities and is playing an important role in enhancing public awareness of Fund finances.

54. Progress has been made in the effort to strengthen safeguards on the use of Fund resources through the conduct of safeguards assessments of central banks. The new framework, which became effective in July 2000, has heightened awareness among central banks and the Fund of the need for adequate safeguards. Toward the end of this year, the Executive Board will review the Fund's experience with the new policy, with the assistance of independent analysis.

55. In 2001, an independent Evaluation Office (EVO) will begin assessing the work of the Fund to improve further the transparency, effectiveness, credibility, and accountability of the Fund. The Director of EVO has been appointed with a view to making the office operational in the coming months. ${ }^{16}$ Reporting to the Board, the EVO will conduct independent evaluations of Fund policy and operations with the full support and cooperation of Fund management. The EVO's work should enhance the credibility of the Fund's work.

\section{Strengthening Financial Sector Work and Surveillance}

56. In the past year, the Fund has intensified its effort to help members to foster financial sector soundness as a precondition for sustained growth. The Fund's work also aims at helping members to take advantage of the opportunities of international financial markets while minimizing the risks.

57. The Financial Sector Assessment Program, Offshore Financial Center assessments and recent initiatives by the Fund (and Bank) to combat financial abuse are important steps to help

${ }^{16}$ The Executive Board has appointed Mr. Montek Singh Ahluwalia as the Director of EVO.

\section{CInternational Monetary Fund. Not for Redistribution}


strengthen the Fund's expertise and judgment, and, in turn, its efficiency and legitimacy, on issues relating to international capital and financial markets.

\section{A. International Capital Market Surveillance}

58. Crisis prevention must be at the heart of Fund surveillance. As countries become more open to capital flows, macroeconomic and domestic policies need to be focused on reducing vulnerability to financial crises. To further strengthen the Fund's work on global capital markets, it was decided in March 2001 to create a new International Capital Markets department. The Fund has also expanded its discussions with private sector market participants through the Capital Markets Consultative Group (CMCG).

Recent Work on International Capital Markets

59. As noted, since September, the Fund has deepened its analysis of capital markets as an integral element of Fund surveillance. International Capital Market Reports continue as the main instrument for Fund Board discussions and surveillance of world capital market developments. In addition, a number of studies on mature and emerging markets have been undertaken including on Over the Counter (OTC) derivatives markets; the consolidation of financial institutions; and the role of foreign financial institutions and private sector involvement in crisis resolution. The Fund now publishes a quarterly report on emerging market financing, which provides in-depth analyses of the risks and opportunities facing emerging market countries in accessing international capital markets focusing on developments in equity, loan, and bond markets.

International Capital Markets Department

60. In March 2001, the Managing Director decided to establish an International Capital Markets Department (ICM) ${ }^{17}$ By consolidating the activities and operations previously spread among several departments, the new department should enable the Fund to conduct more effective surveillance at both the national and international levels, and enhance its capabilities to provide early warning of potential stress in financial markets. The new department will play a central role in the Fund's conceptual work related to the international financial system, systemic issues, and capital market access by member countries. More specifically ICM will:

- deepen the Fund's understanding of capital market operations, and of the forces driving the supply of capital;

${ }^{17}$ In October 2000, the Managing Director asked a panel of experts to provide an independent perspective on how the Fund should organize its financial sector and capital markets work. The group headed by Mr. Lipsky, Chief Economist of J.P. Morgan Chase, presented its report in January 2001

\section{CInternational Monetary Fund. Not for Redistribution}


- $\quad$ strengthen the Fund's capacity for addressing systemic issues related to capital market developments;

- enable the Fund to conduct more effective surveillance at both the national and international levels;

- enhance the Fund's capabilities in providing early warning of potential stress in the financial markets; and

- $\quad$ strengthen the Fund's ability to help member countries gain access to international capital markets, and benefit from and deal with interactions with the international capital markets.

Capital Markets Consultative Group

61. The Fund's contacts with and surveillance of international capital markets have been enhanced by the Capital Markets Consultative Group (CMCG) established by the Managing Director last year. The CMCG brings together senior private sector market participants in an informal forum to discuss: matters of common interest; measures and proposals that could promote a more flexible and efficient financial system; ramifications of the Fund's and others' initiatives; and how to promote the Fund's outreach to the markets. The Group is proving a useful way for the Fund to get a clearer view of how markets are thinking and for the Fund to give its views on developments, and complements ongoing less formal consultation with market participants.

62. The first meeting of the CMCG in September 2000 allowed a dialogue on participants' views of the Fund's crisis prevention initiatives and on the broad framework governing approaches to involving the private sector in the resolution of financial crises. A working group of the CMCG is focusing on how creditor-debtor relations can be strengthened to the benefit of both sides and with the aim of reducing instability in the provision of funds and in market conditions.

\section{B. Strengthening Financial Systems}

63. In light of the rapid globalization of financial markets, the emergence of financial sector problems as an important causal factor of crises over the last decade in several countries, and the important links between the financial sector and a country's overall economic health, the Fund has intensified its focus on financial sector surveillance. Assessment of member countries' financial sector vulnerabilities has been strengthened through the joint Bank-Fund FSAP and Fund's OFC initiative.

Financial Sector Assessment Program (FSAP)

64. The FSAP is designed to help countries enhance their resistance to crises and cross-border contagion, and to foster growth, by promoting financial system soundness

\section{(C)International Monetary Fund. Not for Redistribution}


and development. The value of the program derives to a large extent from its joint nature, as well as from the expert support it receives from various cooperating institutions including central banks, supervisory agencies, other institutions, and standard setters (Table 4). ${ }^{18}$ This ensures consistency of policy advice by the Fund and the Bank, economizes on scarce expert resources, and enhances the program's legitimacy.

65. The experience gained from assessments and the feedback and support received from participating countries and cooperating institutions was reviewed by the Executive Boards of the Fund and the World Bank in December 2000 and January 2001,

respectively. ${ }^{19}$ The Program received strong support from both Boards, with the Fund's

Board finding that the FSAP process provides a coherent and comprehensive framework: to identify financial system vulnerabilities and strengthen the analysis of macroeconomic and financial stability issues; to assess financial sector development needs and priorities; and to help authorities develop appropriate policy responses. The Fund's Board agreed that Financial System Stability Assessments (FSSAs) are the preferred tool for strengthening the monitoring of financial systems under the Fund's Article IV surveillance.

66. Based on their reviews, the Executive Boards of the Fund and the Bank established guidelines for the FSAP in the period ahead.

- There was agreement that the program should continue at a similar or somewhat higher intensity than before (up to 24 country assessments per year). Within any one year, priority would be given to countries of systemic importance and those with external sector weaknesses or financial vulnerability. However, the ultimate goal is to assess the entire membership so that all countries have the opportunity to benefit from the program.

- With a view to maintaining adequate monitoring of financial sector systems in years between full assessments, for countries that have already participated in the FSAP, focused updates of FSSA findings could be undertaken in the context of subsequent Article IV consultations. In cases where a country volunteers to participate in the FSAP, but cannot be accommodated in the program immediately, or if a country chooses not to participate in the FSAP, Article IV mission teams could be reinforced with financial sector experts. Nevertheless, the full FSAP exercise remains the preferred vehicle for conducting financial sector assessments as input to Fund surveillance.

\footnotetext{
${ }^{18}$ These institutions support the FSAP by helping as needed to identify experts, and by sharing information on assessment methodologies

${ }^{19}$ For more details see Public Information Notice, "IMF Reviews Experience with the Financial Sector Assessment
} Program-FSAP —and Reaches Conclusion on Issues Going Forward", February 5, 2001.

\section{CInternational Monetary Fund. Not for Redistribution}


- $\quad$ Fund staff, in collaboration with other international organizations and standard setting bodies, will further develop analytical techniques for use in FSAPs, including macro prudential indicators, stress tests and scenario analysis, and assessment methodologies of financial sector standards.

- To emphasize the importance of follow-up by the Bank and the Fund, both institutions will seek to ensure that the strategic components of the assessment are reflected in other aspects of country work, and that appropriate technical assistance and other support be provided to national authorities that request it with a view to building the necessary institutional capacity.

- At the December 2000 review, the Fund's Executive Board decided that FSSAs could be published after the conclusion of the associated Article IV consultation, if the member concerned so requests. However, in light of the conditions under which the Board approved the pilot study, publication of the FSSAs for the twelve countries participating in the FSAP pilot was not authorized.

Offshore Financial Centers (OFCs)

67. In July 2000, the Board asked Fund staff to extend financial sector work to include offshore financial centers. The program involves voluntary assessments encompassing three possible modules: self-assessments of relevant standards (module 1); stand-alone Fund assessments of relevant standards (module 2); and comprehensive assessments of risks, vulnerabilities, institutional preconditions, and standards observance within an FSAP-type framework (module 3).

68. Seventeen OFCs missions had been fielded by the end of March 2001. These missions were intended to determine the nature and scale of the financial services industry; as well as to gather information on financial sector regulation and supervision. The missions found that most OFCs were keen to begin with an assisted self-assessment of relevant standards, and to have an opportunity to make changes both to legislation and supervision, before embarking on a Fund-led module 2 or module 3 assessment. Several OFCs also asked for technical assistance.

69. In 2001 the Fund plans to send missions to about $\mathbf{2 5}$ jurisdictions. Priorities for 2001 include: those OFCs willing to undergo a module 2 assessment and those OFCs most keen to involve the Fund in their plans for raising standards. The work on OFCs is being developed in consultation with other relevant bodies, such as offshore supervisory groupings and other national supervisory agencies. This cooperation is designed both to minimize the administrative burden on OFCs, and to enhance access by Fund-led missions to supervisory experts, including some from OFCs. 


\section{Combating Money Laundering}

70. At the request of the IMFC, the Fund is enhancing its contributions to the international efforts to combat money laundering. ${ }^{20}$ At a meeting on April 13, the Executive Board of the Fund agreed that money laundering is a problem of global concern, affecting major financial markets as well as smaller ones, and that international cooperation needed to be stepped up. Directors also agreed that the Fund has an important role to play in protecting the integrity of the international financial system, including through efforts to combat money laundering. The Fund's involvement in this area will be strictly confined to its core areas of competence, and in particular the Fund would not become involved in law enforcement activities.

71. The Fund will take the following steps to enhance international efforts to counter money laundering:

- intensify its focus on anti-money laundering elements in all relevant supervisory principles;

- $\quad$ work more closely with major international anti-money laundering groups;

- $\quad$ increase the provision of technical assistance;

- include anti-money laundering concerns in its surveillance and other operational activities when macroeconomic relevant; and

- $\quad$ undertake additional studies and publicizing the importance of countries acting to protect themselves against money laundering.

72. The main focus of the Fund's efforts will continue to be centered on financial supervision principles: the anti-money laundering elements - particularly know-yourcustomer rules of these principles - will help ensure that financial institutions have in place the management and risk control systems needed to deter money laundering. To deepen the Fund's involvement, a methodology for assessing financial standards relevant to countering money laundering will be developed, and it will be used to prepare a new section in reports for the Financial Sector Assessment Programs.

73. It was generally agreed that the Financial Action Task Force (FATF) 40 Recommendations be recognized as the appropriate standard for combating money laundering, and that work should go forward to determine how the Recommendation could be adapted and made operational to the Fund's work. Directors stressed that the FATF process needs to be made consistent with the ROSC process - that is, the FATF standard needs to be applied uniformly, cooperatively, and on a voluntary basis - and that

${ }^{20}$ Communique of the IMFC of the Board of Governors of the IMF, September 24, 2000.

\section{CInternational Monetary Fund. Not for Redistribution}


once this is done, the FATF could be invited to participate in the preparation of a ROSC module on money laundering.

74. In future, the Fund and the Bank will work more closely with the FATF and other anti-money laundering groups, on information exchange, on the revision of the FATF 40 Recommendations, and on their assessment procedures. The Fund Board requested the staff to come back with a progress report and proposals. 
Figure 1. Average Number of Structural Conditions per Program Year by Type of Country 1/

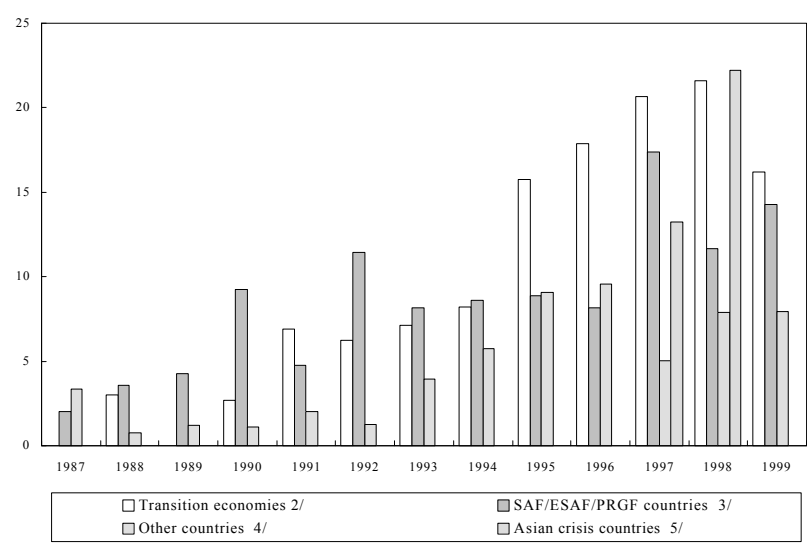

Source: International Monetary Fund, MONA database; and country paper

1/ Total number of performance criteria, prior actions, conditions for completion of review, and structural benchmarks per program, adjusted for differences in program length. 2/ As defined in the World Economic Outlook, covering former centrally planned economies in Eastern Europe, FSU countries, and Mongolia. 3/ Countries with SAF/ESAF/PRGF-supported arrangements, excluding transition economies.
4/ Residual group, encompassing programs in countries that do not fall into any of the other categories.
5/ Indonesia, Korea, and Thailand.

CInternational Monetary Fund. Not for Redistribution 
Figure 2. Distribution of Structural Conditions by Economic Sector (In percent of total structural conditions 1/)

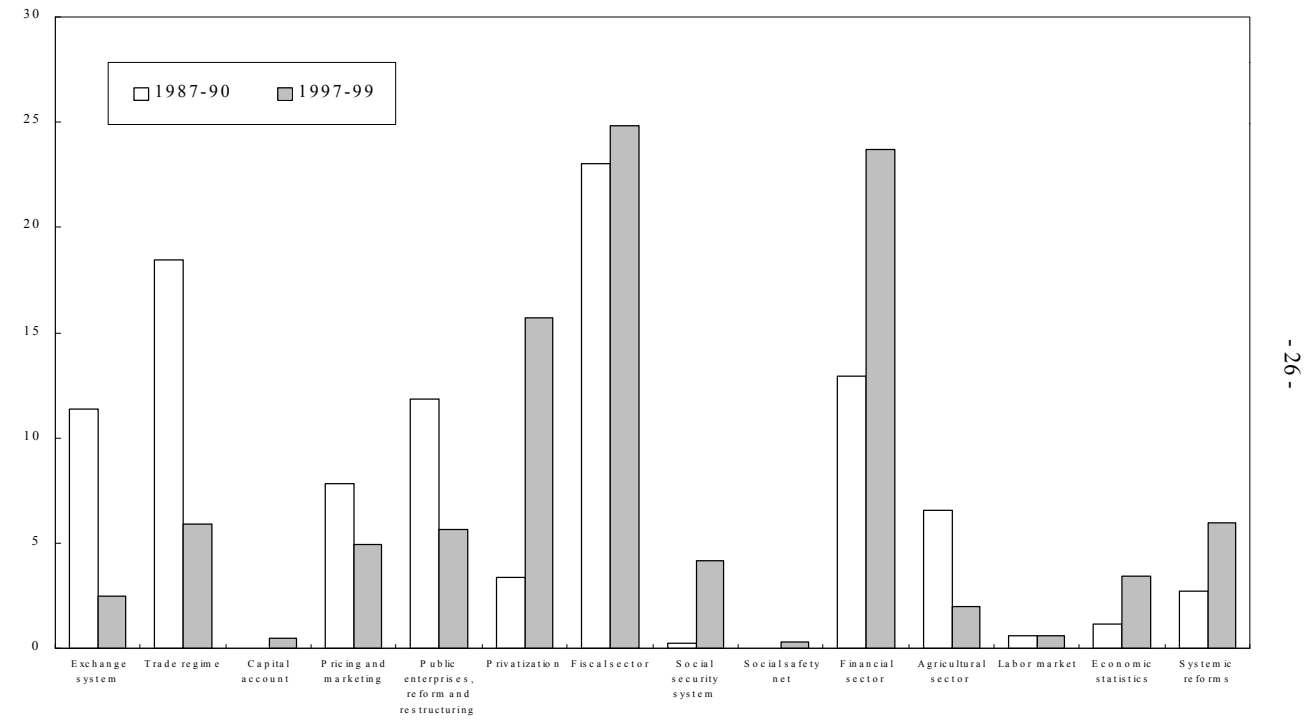

Source: International M onetary Fund, MONA database; and country papers.

1/ Averages of the sectoral distributions of total structural conditions (performance criteria, structural benchmarks, prior actions, and conditions for

CInternational Monetary Fund. Not for Redistribution 
Table 1. Fund Credit Facilities

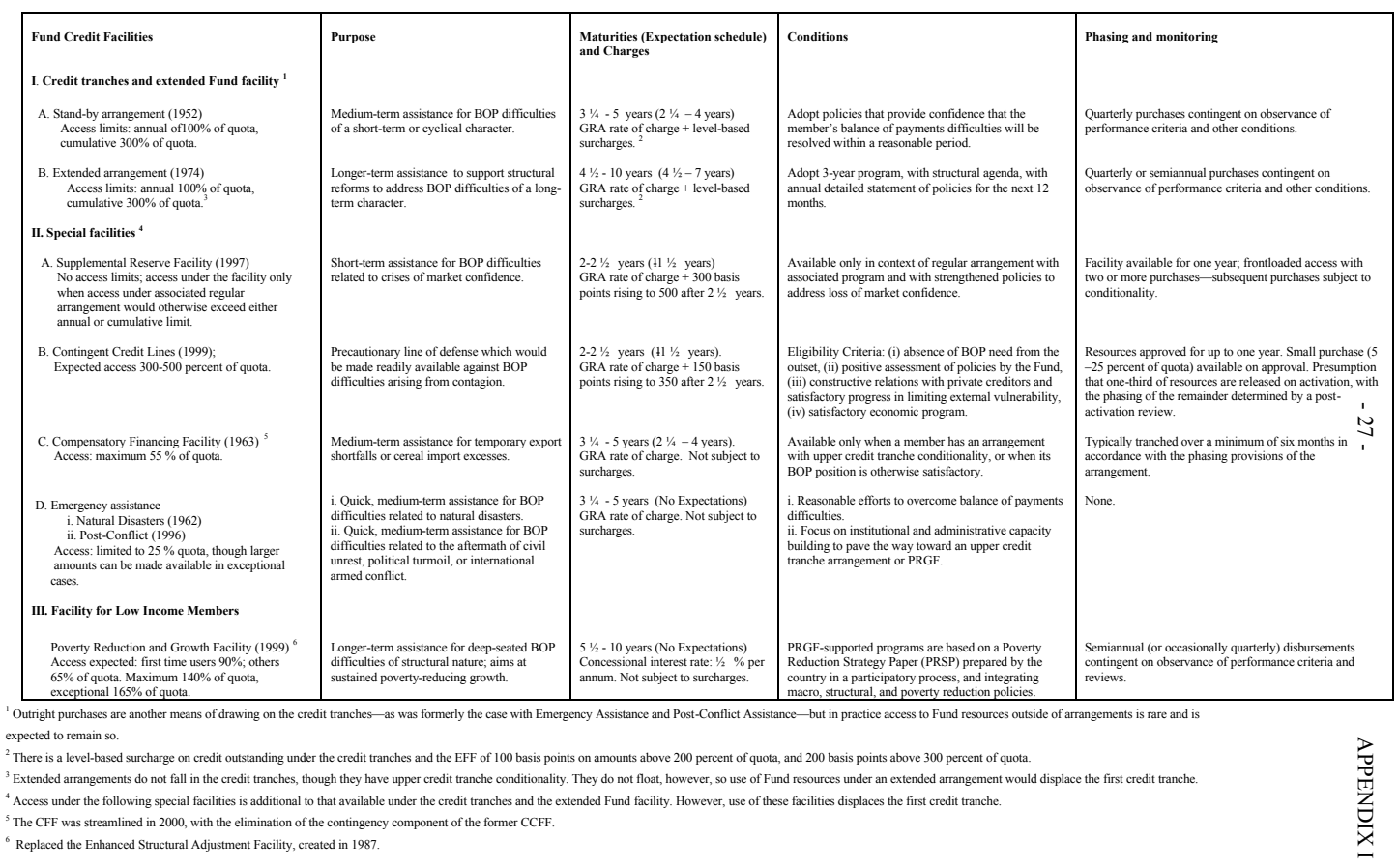




\begin{tabular}{|c|c|c|c|c|c|c|c|c|}
\hline & $\underset{\text { Africa }}{(1)}$ & $\underset{\text { Asia }}{(2)}$ & $\begin{array}{c}\text { contr } \\
\substack{\text { Central and } \\
\text { Eastem } \\
\text { Europe }}\end{array}$ & $\begin{array}{c}\text { (4) } \\
\text { clsand } \\
\text { Mongolia }\end{array}$ & 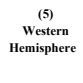 & $\begin{array}{l}\text { (a) } \\
\text { Midale east, } \\
\text { Malta, and } \\
\text { Turkey }\end{array}$ & 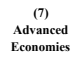 & $\begin{array}{c}\text { (8) } \\
\text { Total IMF } \\
\text { Members }\end{array}$ \\
\hline Number of Countries & 51 & 28 & 16 & 12 & 32 & 16 & 28 & 183 \\
\hline Intitiatives: & & & & & & & & \\
\hline $\begin{array}{c}\text { sDDS Subscriber } \\
\text { Number of countries } \\
\text { Percentage }\end{array}$ & $\begin{array}{l}1 \\
2 \%\end{array}$ & $\begin{array}{c}5 \\
18 \%\end{array}$ & $\begin{array}{c}9 \\
56 \%\end{array}$ & $0 \%$ & $\underset{25 \%}{8}$ & $\begin{array}{l}1 \\
6 \%\end{array}$ & $\begin{array}{c}23 \\
82 \%\end{array}$ & $\begin{array}{l}47 \\
26 \%\end{array}$ \\
\hline $\begin{array}{l}\text { PIN Published } \\
\text { Number of countries } \\
\text { Percentage }\end{array}$ & $\begin{array}{l}40 \\
78 \%\end{array}$ & $\begin{array}{l}20 \\
71 \%\end{array}$ & $\begin{array}{r}15 \\
94 \%\end{array}$ & $\begin{array}{l}10 \\
83 \%\end{array}$ & $\begin{array}{l}30 \\
94 \%\end{array}$ & $\begin{array}{r}51 \% \\
\end{array}$ & $\begin{array}{l}27 \\
96 \%\end{array}$ & $\begin{array}{l}147 \\
80 \%\end{array}$ \\
\hline $\begin{array}{l}\text { Article IV Staft Report Pullikhed } \\
\text { Number of countries } 3 / \\
\text { Percentage }\end{array}$ & $\begin{array}{c}12 \\
24 \%\end{array}$ & $\begin{array}{c}4 \\
14 \%\end{array}$ & $\begin{array}{l}11 \\
69 \%\end{array}$ & ${ }_{8 \%}^{1}$ & $\begin{array}{c}16 \\
50 \%\end{array}$ & $\frac{1}{6 \%}$ & $\begin{array}{l}{ }_{86 \%}^{24} \\
\end{array}$ & $\begin{array}{l}69 \\
38 \%\end{array}$ \\
\hline $\begin{array}{l}\text { FSAPs, Completed So Far } \\
\text { Number of countries } \\
\text { Percentage }\end{array}$ & $\underset{4 \%}{2}$ & $\stackrel{1}{4 \%}$ & $\underset{13 \%}{2}$ & $8 \%$ & $6 \%$ & $\begin{array}{c}3 \\
19 \%\end{array}$ & $7 \%$ & $\begin{array}{l}13 \\
7 \%\end{array}$ \\
\hline $\begin{array}{l}\text { FSAPs, Completed and Committed } \\
\text { Number of countries } \\
\text { Percentage }\end{array}$ & $\begin{array}{c}8 \\
16 \%\end{array}$ & $\begin{array}{c}3 \\
11 \%\end{array}$ & $\begin{array}{l}7 \\
44 \%\end{array}$ & $\begin{array}{c}3 \\
25 \%\end{array}$ & $\begin{array}{l}10 \\
31 \%\end{array}$ & $\begin{array}{r}5 \\
31 \%\end{array}$ & $\begin{array}{c}13 \\
46 \%\end{array}$ & $\begin{array}{l}49 \\
27 \%\end{array}$ \\
\hline 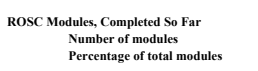 & $\begin{array}{l}22 \\
21 \%\end{array}$ & $\begin{array}{l}10 \\
9 \%\end{array}$ & $\begin{array}{l}23 \\
21 \%\end{array}$ & $\begin{array}{l}10 \% \\
9 \%\end{array}$ & $\begin{array}{l}10 \\
9 \%\end{array}$ & $8 \%$ & $\begin{array}{l}23 \\
21 \%\end{array}$ & 111 \\
\hline $\begin{array}{l}\text { ROSC Modules, Completed and Committed } \\
\text { Number of modulus } 4 / \text { mmmltes } \\
\text { Percentage of total modules }\end{array}$ & $\begin{array}{l}53 \\
19 \%\end{array}$ & $\begin{array}{l}23 \\
8 \%\end{array}$ & $\begin{array}{c}47 \\
16 \%\end{array}$ & $\begin{array}{l}26 \\
9 \%\end{array}$ & $\begin{array}{c}47 \\
16 \%\end{array}$ & $\begin{array}{l}23 \\
8 \%\end{array}$ & $\begin{array}{l}63 \% \\
23 \%\end{array}$ & 290 \\
\hline
\end{tabular}


Table 3. Publication of Policy PINs, Summings Up and Papers

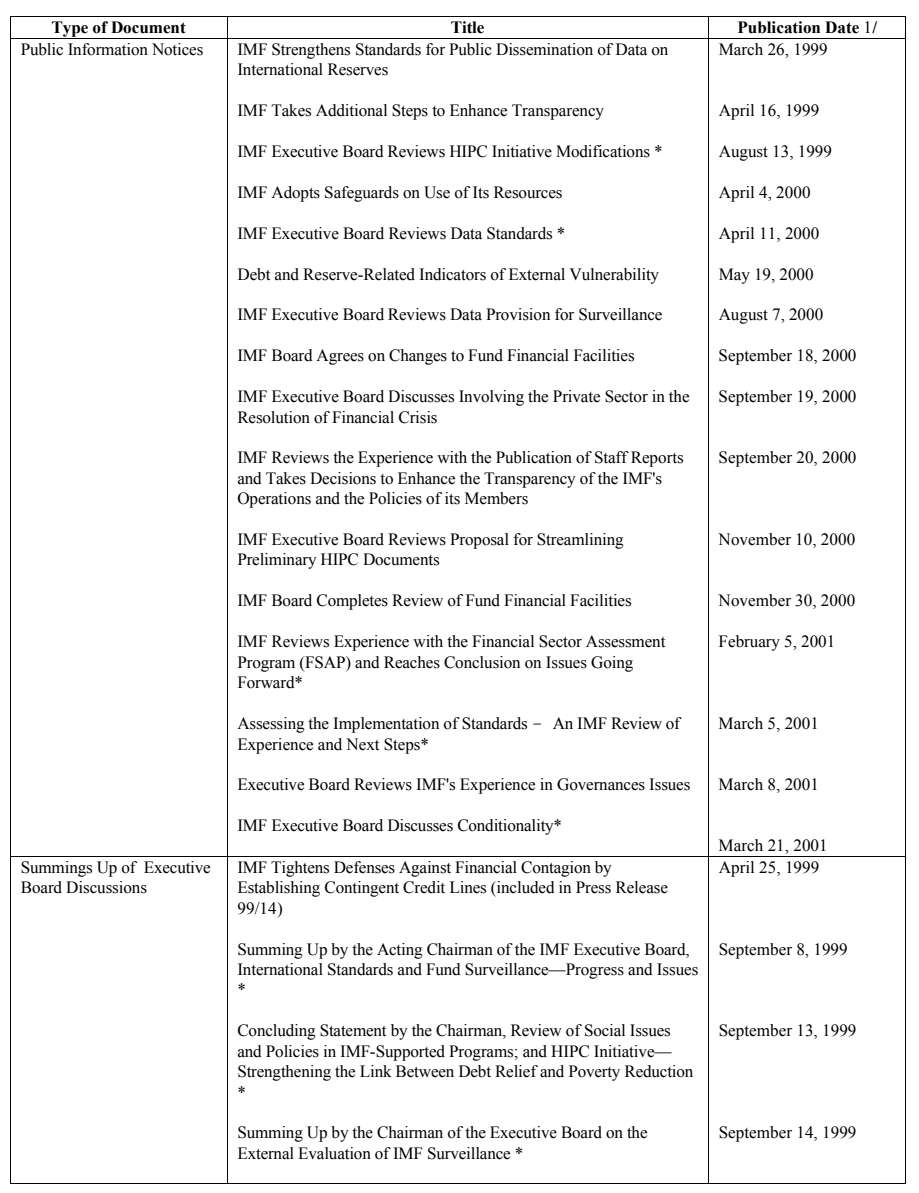


$-30-$

APPENDIX III

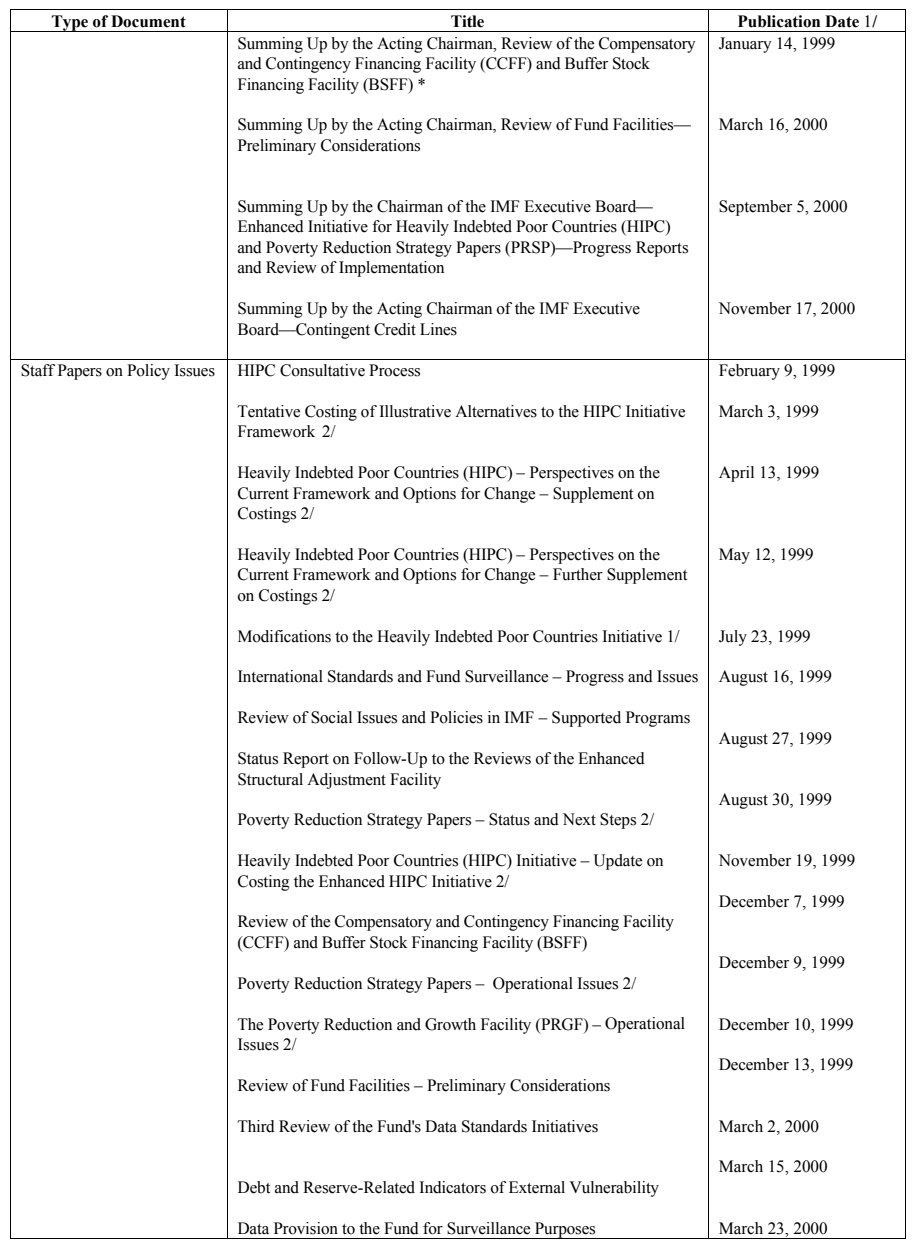

CInternational Monetary Fund. Not for Redistribution 
$-31-$

APPENDIX III

\begin{tabular}{|c|c|c|}
\hline \begin{tabular}{|l|} 
Type of Document \\
\end{tabular} & Title & Publication Date 1 \\
\hline & $\begin{array}{l}\text { Draft Guidelines for Public Debt Management } \\
\text { Review of Fund Facilities-Follow-Up } \\
\text { Heavily Indebted Poor Countries Initiative and Poverty Reduction } \\
\text { Strategy Papers - Progress Reports } \\
\text { Key Features of PRGF - Supported Programs } \\
\text { Poverty Reduction Strategy Papers - Progress in Implementation } \\
\text { Enhanced Initiative for Heavily Indebted Poor Countries - Review } \\
\text { of Implementation } \\
\text { Involving the Private Sector in the Resolution of Financial Crises- } \\
\text { Standstills - Preliminary Considerations } \\
\text { HIPC Initiative - Country Implementation Status Notes } \\
\text { Data Template on International Reserves and Foreign Currency } \\
\text { Liquidity - Database and Dissemination of Data } \\
\text { Initiative for Heavily Indebted Poor Countries - Proposal for } \\
\text { Streamlining Preliminary Documents } \\
\text { Debt Service Payments After HIPC Initiative Assistance } \\
\text { Involving the Private Sector in the Resolution of Financial Crises- } \\
\text { Restructuring International Sovereign Bonds } \\
\text { Progress on the HIPC Initiative and PRSP Program } \\
\text { Progress in Strengthening the Architecture of the International } \\
\text { Financial System and Reform of the IMF } \\
\text { Financial Implications of the Shrinking Supply of U.S. Treasury } \\
\text { Debt } \\
\text { Conditionality in Fund-Supported Programs } \\
\text { Financial Sector Assessment program - A Review - Lessons from } \\
\text { the Pilot and Issues Going Forward } \\
\text { Assessing the Implementation of Standards - A Review of } \\
\text { Experience and Next Steps }\end{array}$ & $\begin{array}{l}\text { August 7, } 2000 \\
\text { August } 15,2000 \\
\text { August } 31,2000 \\
\text { September } 7,2000 \\
\text { September 7, } 2000 \\
\text { September } 8,2000 \\
\text { September } 8,2000 \\
\text { September } 21,2000 \\
\text { September } 23,2000 \\
\text { October } 13,2000 \\
\text { November } 10,2000 \\
\text { November } 30,2000 \\
\text { February } 5,2001 \\
\text { February } 15,2001 \\
\text { March 9, 2001 } \\
\text { March 20, 2001 } \\
\text { March 21, 2001 } \\
\text { March 23, 2001 } \\
\text { March } 27,2001\end{array}$ \\
\hline
\end{tabular}

1/ Documents published from January 1999 to March, 2001. Where the date of publication on the Fund's website is not available, the date given is the date the document was issued to the Fund's Executive Board. Asterisks denote PINs or

Summings Up for which the associated policy papers have been published.

Joint papers for Fund and World Bank Executive Boards. 


\section{Table 4. Institutions Cooperating in the FSAP by Providing Experts (Current and Prospective) \\ Central Banks and Supervisory Agencies}

Central Bank of Argentina

Reserve Bank of Australia

Australian Prudential Regulatory Authority

Austrian National Bank

National Bank of Belgium

Banking and Finance Commission, Belgium

Central Bank of Brazil

Bank of Canada

Office of the Superintendent of Financial Institutions, Canada

Banking Commission of the Central African States

Bank of Central African States (BEAC)

Central Bank of Chile

Superintendency of Banks and Financial Institutions, Chil

Hong Kong Monetary Authority

Central Bank of Colombia

Czech National Bank

National Bank of Denmark

Financial Supervisory Authority, Denmark

European Central Bank

Bank of Finland

Financial Supervision Authority, Finland

Bank of France

Deutsche Bundesbank

Financial Supervisory Authority, Hungary

National Bank of Hungary

Reserve Bank of India

Central Bank of Ireland

Bank of Israel

Bank of Italy

African Development Bank

Inter-American Development Bank

International Standards Setting Bodies

Basel Committee on Banking Supervision (BCBS)

International Association of Insurance Supervisors (IAIS)

International Accounting Standards Committee (IAS)

International Organization of Securities Commissions (IOSCO)

Committee on Payment and Settlement Systems (CPSS)

\section{Other Institutions}

Bank of Japan

Financial Services Agency, Japan

Bank Negara Malaysia

Bank of Mexico

Netherlands Bank

Reserve Bank of New Zealand

New Zealand Securities Commission

Central Bank of Norway

Banking, Insurance and Securities

Commission, Norway

Central Reserve Bank of Peru

National Bank of Poland

Bank of Portugal

Saudi Arabian Monetary Agency

Monetary Authority of Singapore

Reserve Bank of South Africa

Bank of Spain

Bank of Sweden

Financial Supervisory Authority, Sweden

Swiss National Bank

Central Bank of Tunisia

Central Bank of the Republic of Turkey

Bank of England

U.K. Financial Services Authority

U.S. Federal Reserve System

U.S. Federal Deposit Insurance Corporation

U.S. Office of the Comptroller of the Currency

Banking Commission of West African States

Central Bank of West African States (BCEAO)

Bank for International Settlements 